\title{
PENGEMBANGAN SISTEM CERDAS MENGGUNAKAN PENALARAN BERBASIS KASUS (CASE BASED REASONING) UNTUK DIAGNOSA PENYAKIT AKIBAT VIRUS EKSANTEMA
}

\author{
Agus Sasmito Aribowo \\ Jurusan Teknik Informatika UPN "Veteran" Yogyakarta \\ Jl. Babarsari 2 Tambakbayan 55281 Telp (0274)485323 \\ Email : sasmito_skom@yahoo.com
}

\begin{abstract}
Disease caused by a exanthema virus is a common disease in Indonesia. There are many types of diseases caused by this virus. Examples are chicken pox, measles, variola, etc. with symptoms almost similar to each other. To correctly identify the symptoms need experts. But the problem is very limited number of experts. Then the expert system is needed which has been given by the expert knowledge to assist in the diagnosis. Expert system in this research uses a case-based reasoning approach. If there is a similar case, the reasoning for considering the case of the nearest using Probabilistic Bayes. The result is the system will still be able to provide the best recommendations solution for new cases based on the solution to an old case that the nearest level of similarity.

Keyword : Eksantema viruses, Case-Based Reasoning, Probabilistic Bayes

Penyakit yang disebabkan oleh virus eksantema merupakan penyakit yang umum terjadi di Indonesia. Jenis-jenis penyakit yang disebabkan oleh virus ini cukup banyak. Contohnya adalah cacar air, campak, variola, dan sebagainya dengan gejala yang hampir mirip satu sama lain. Untuk mengidentifikasi secara benar berdasarkan gejalanya perlu seorang ahli yang berkompeten. Tetapi permasalahannya jumlah ahli sangat terbatas. Maka dibutuhkan sistem pakar yang telah diberi pengetahuan oleh ahli untuk membantu proses diagnosa. Sistem pakar dalam penelitian ini menggunakan pendekatan penalaran berbasis kasus. Jika ada kasus yang mirip maka penalaran untuk menimbang kasus terdekat menggunakan metode Probabilitas Bayes. Hasilnya sistem akan tetap dapat memberikan rekomendasi solusi terbaik bagi kasus baru berdasarkan solusi kasus lama yang terdekat tingkat kemiripannya.

Kata Kunci : Eksantema virus, Penalaran Berbasis Kasus, Probabilitas Bayes
\end{abstract}

\section{PENDAHULUAN}

Hasil survai di Indonesia terhadap kesehatan anak menunjukkan bahwa 42,8\%-96\% anak yang termasuk kelompok 0-4 tahun masih mudah terserang penyakit yang disebabkan oleh eksantema virus. Jenis-jenis penyakit yang disebabkan oleh eksantema virus contohnya adalah cacar air, campak dan variola. Cacar air memang merupakan penyakit anak-anak yang sudah ratusan tahun dikenal orang. Sebagian masyarakat, khususnya orang tua memang ada yang peduli pada penyakit yang diderita anaknya, tapi karena mahalnya biaya konsultasi dokter spesialis dan jarangnya tenaga dokter maka kebanyakan masyarakat menyembuhkan penyakit cacar yang diderita anaknya dengan cara apa adanya. Pengetahuan masyarakat tentang penyakit disebabkan oleh eksantema virus masih kurang sehingga ketika anak-anak terkena suatu penyakit golongan ini mereka sering salah mengerti dengan menduga bahwa itu bukan penyakit akibat eksantema virus melainkan penyakit lain. Misalnya kalau terkena cacar air akan timbul ruam, masyarakat mengira terkena alergi biasa. Selain itu jenis-jenis penyakit akibat eksantema virus cukup banyak. Umumnya memiliki gejala yang hampir mirip. Padahal setiap jenis penyakit memiliki obat dan cara penanganan tersendiri. Oleh karena itu penelitian dititikberatkan pada pengembangan sistem pakar berbasis kasus untik diagnosa secra teliti penyakit anak yang disebabkan oleh eksantema virus.

Seiring perkembangan ilmu pengetahuan dan teknologi informasi maka keberadaan seorang ahli dapat digantikan oleh komputer. Sistem ini dinamai dengan Sistem Pakar. Biaya pembuatan Sistem Pakar relatif lebih murah bila dibandingkan untuk menjadi seorang pakar. Sistem ini dapat digunakan pada lingkungan kerja yang mungkin dapat membahayakan 
manusia, misalnya di daerah endemi. Sifat kepakaran yang dimilikinya permanen, dapat dikembangkan, dan umumnya dilengkapi dengan fasilitas yang dapat mengolah proses penalaran yang digunakan untuk menarik kesimpulan. Karena memiliki sifat komputer maka responnya cepat dan dapat diandalkan setiap saat.

Untuk lebih fokus dalam pembangunan sistem pakar tersebut, maka sistem akan dibatasi untuk mendeteksi sebelas penyakit yang diakibatkan oleh Eksantema Virus antara lain : Varisela (Chicken pox, cacar air), Variola (Small pox, cacar), Rubeola (Measles, campak), Rubela (German measles, campak jerman), Infeksi Enterovirus, Hand-Foot-and-Mouth Syndrome, Mononukleosis Infeksiosa, Infeksi Cytomegalovirus Kongenital, Roseola Infantum (eksantema subitum), Eritema Infeksiosum, Sindrom Gianotti - Crust. Pendekatan penalaran menggunakan penalaran berbasis kasus (Case Based Reasoning), artinya sistem pakar akan melakukan diagnosa dengan cara mencocokkan kasus baru yang hendak didiagnosa dengan mencari kasus-kasus yang mirip atau hampir mirip di yang sudah pernah direkam dalam sistem. Kemudian solusi dari kasus direkam tersebut dijadikan rekomendasi solusi kasus baru tersebut.

\section{TINJAUAN PUSTAKA}

\subsection{PENALARAN BERBASIS KASUS}

Penalaran berbasis kasus (Case-Base Reasoning) merupakan sebuah sistem yang menggunakan pengalaman lama untuk dapat mengerti dan menyelesaikan masalah baru. (Swoboda, 1994)

\subsection{Tahapan proses sistem penalaran komputer berbasis kasus:}

a. Retrieve:

Proses retrieve adalah proses ekstraksi kasus yang mirip dengan kasus baru dari kasuskasus yang lama.

b. Reuse:

Menggunakan kembali informasi dan pengetahuan dalam kasus tersebut untuk mengatasi masalah. Proses Reuse yaitu pada saat ditemukannya gejala yang sama yang ada dalam database dengan gejala pada kasus sekarang. Informasi tersebut akan dilakukan untuk menghitung nilai similarity antar kasus dan gejala yang menggunakan algoritma knn dan indexing untuk mendapatkan data terurut.

c. Revisi :

Meninjau ulang solusi yang diajukan. Revise dilakukan terhadap gejala baru yang tidak ada didalam databse yang akan disimpan ke dalam tabel new gejala. Dari tabel tersebut maka akan ditampilkan beberapa gejala baru yang akan dimasukkan kedalam tabel gejala oleh pakar.

d. Retain:

Mendalami bagian dari pendalaman ini untuk digunakan dalam pemecahan masalah berikutnya. Proses Retain dilakukan dengan menyimpan hasil gejala baru kedalam sebuah case-base sehingga dapat digunakan sebagai kasus baru baik menggunakan bantuan gejala lain atau gejala itu sendiri. gambar proses terjadinya case-base reasoning dimulai dari retrieve, reuse, revise dan retain. 


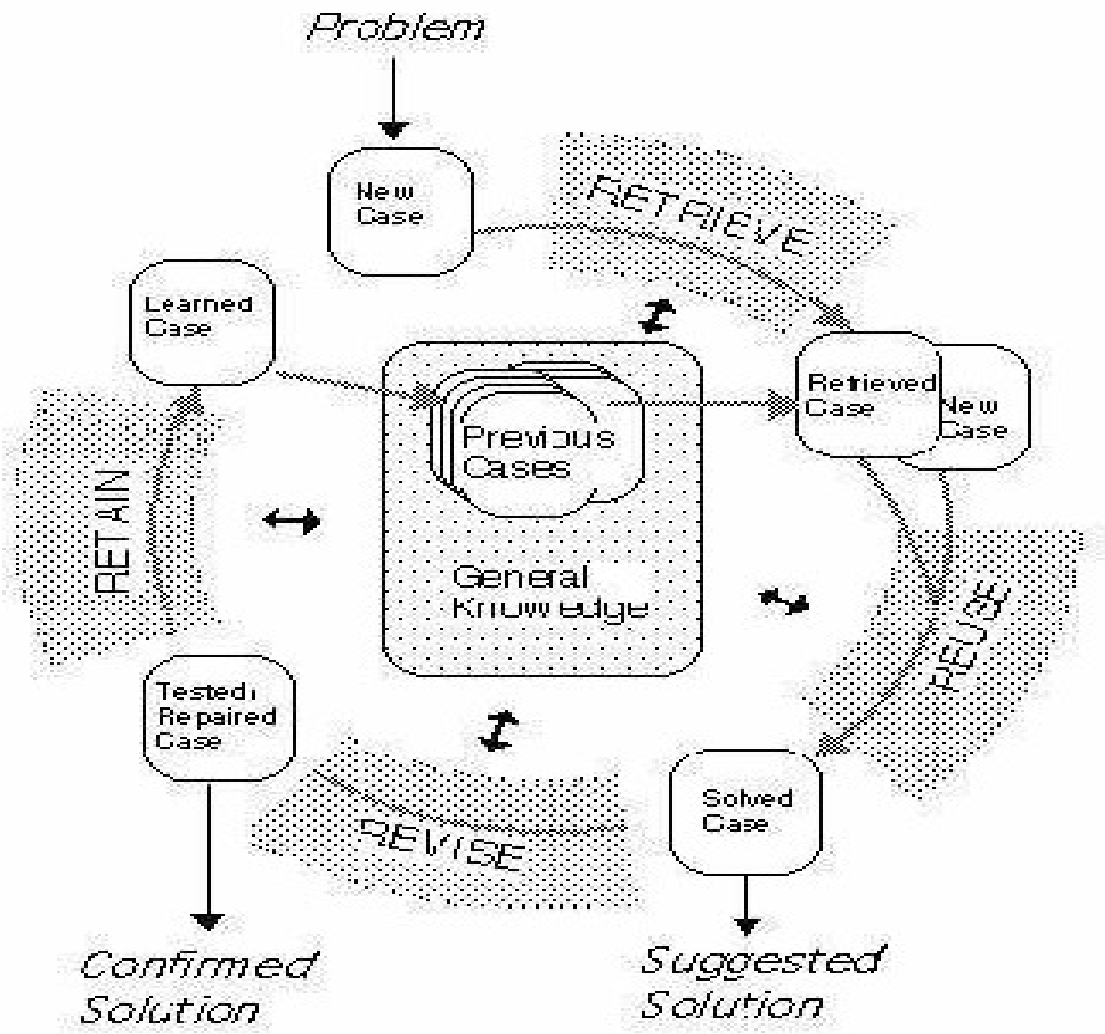

Gambar 1. Siklus Case-Base Reasoning.

\subsection{Teknik Indexing}

Pada umumnya sistem basis data sudah menggunakan indeks, dimana indeks adalah struktur data yang mengatur record data pada disk untuk mengoptimalkan beberapa jenis operasi pengambilan (retrieval) tertentu. Indeks memungkinkan pengguna untuk secara efektif mengambil semua record yang memenuhi syarat pencarian pada field search key dari indeks. Pada kasus ini indexing kasus dilakukan pada jenis data yang dapat diindeks yaitu jenis kelamin dan usia. Sedangkan data gejala dan penyakit tidak dapat dijadikan sebagai kunci indeks.

\subsection{Representasi Kasus}

Penalaran berbasis kasus tergantung pada struktur dan isi dari koleksi dari kasus. Suatu kasus dapat diselesaikan dengan memanggil kembali kasus sebelumnya yang sesuai/cocok dengan kasus baru. Representasi kasus untuk kasus-kasus dalam mengidentifikasi penyakit eksantema berdasarkan gejalanya disusun dalam bentuk frame seperti pada tabel berikut .

Tabel 1. Representasi menggunakan frame.

\begin{tabular}{|c|c|c|c|c|c|c|c|c|c|c|}
\hline \multirow[t]{2}{*}{ No. } & \multirow[t]{2}{*}{ Nama } & \multirow[t]{2}{*}{ Sex } & \multirow[t]{2}{*}{ Usia } & \multicolumn{5}{|c|}{ Gejala } & \multirow[t]{2}{*}{ Nama Penyakit } & \multirow{2}{*}{ Solusi } \\
\hline & & & & 1 & 2 & 3 & 4 & $\ldots \mathrm{n}$ & & \\
\hline 1 & A & $\mathrm{L}$ & 6 & $\sqrt{ }$ & & $\sqrt{ }$ & & & Variola (Small pox) & Solusi 1 \\
\hline 2 & $\mathrm{~B}$ & $\mathrm{P}$ & 5 & $\sqrt{ }$ & $\sqrt{ }$ & & & & Cacar air & Solusi 2 \\
\hline 3 & $\mathrm{C}$ & $\mathrm{L}$ & 10 & & $\sqrt{ }$ & $\sqrt{ }$ & $\sqrt{ }$ & $\sqrt{ }$ & Campak & Solusi 3 \\
\hline : & & & & & & & & & & \\
\hline $\mathrm{m}$ & & & & & & & & & & \\
\hline
\end{tabular}


Dari tabel terdapat $\mathrm{m}$ kasus dan $\mathrm{n}$ gejala. Setiap nomor kasus memiliki nama penyakit eksantema serta gejalanya. Kasus-kasus bisa memiliki nama penyakit yang sama dengan gejala yang berbeda.

\subsection{Retrival dan Similarity}

Perhitungan tingkat Similarity kasus baru dengan kasus-kasus lama yang ada dalam database menggunakan metode Probabilitas Bayes. Proses dilakukan setelah proses retrieve informasi dari data kasus lama yang sudah terindex. Hasil proses retrieve sangat mungkin berupa beberapa kasus yang mirip dan dekat dengan kasus baru tersebut. Untuk memilih satu dari beberapa kasus termirip perlu manajemen ketidakpastian. Ketidakpastian ini akan dihitung menggunakan teorema probabilitas bayes, dengan rumus sebagai berikut:

$$
p\left(H_{i} \mid E\right)=\frac{p\left(E \mid H_{i}\right)^{*} p\left(H_{i}\right)}{\sum_{k=1}^{n} p\left(E \mid H_{i}\right)^{*} p\left(H_{i}\right)}
$$

Dimana :

$p\left(H_{i} \mid E\right)=$ probabilitas hipotesis $H_{i}$ benar jika diberikan evidence $E$

$p\left(E \mid H_{i}\right)=$ probabilitas munculnya evidence $E$ jika diketahui hipotesis $H_{i}$ benar

$\mathrm{p}\left(\mathrm{H}_{\mathrm{i}}\right) \quad$ = probabilitas hipotesis tanpa memandang evidence sebelumnya

$\mathrm{n}$ = jumlah hipotesis yang mungkin

\section{METODOLOGI PENELITIAN}

\subsection{Analisis Kebutuhan Sistem}

Sistem yang dibutuhkan harus dapat melakukan proses identifikasi penyakit eksantema berdasarkan kasus-kasus mirip yang sudah ada. Sehingga secara mendetil sistem harus dapat melakukan hal-hal sebagai berikut :

1. Mendata jenis-jenis penyakit akibat eksantema virus, gejala dan solusinya.

2. Menyimpan data kasus penyakit akibat eksantema virus dalam database menggunakan pengindexan terhadap jenis kelamin dan usia.

3. Melakukan proses retrieve data kasus dan menghitung similaritas kasus menggunakan metode probabilitas bayes.

4. Memberikan hasil diagnosa berupa nama penyakit eksantema dan solusinya.

\section{B. Perancangan Sistem}

1. Data Flow Diagram (DFD)

a. Diagram alir data level 0

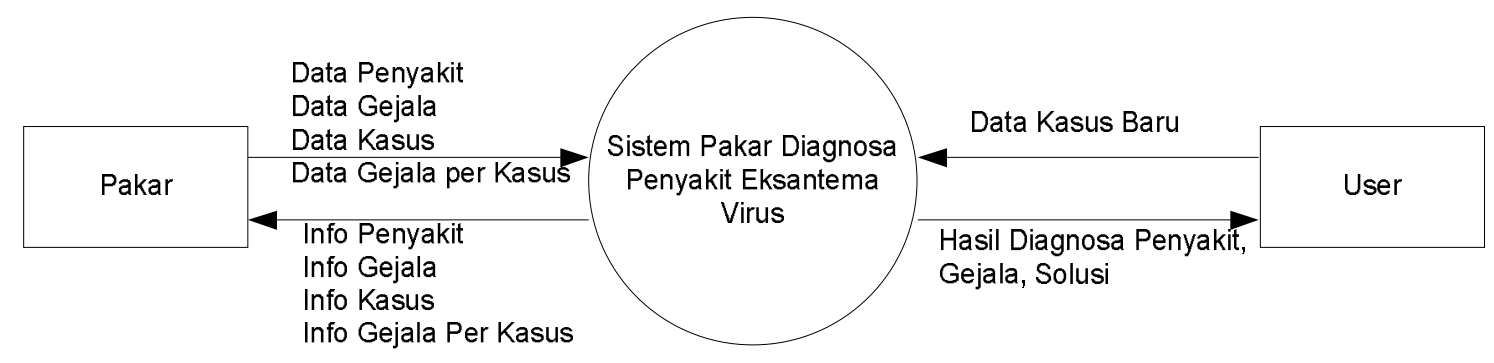

Gambar 2. Diagram alir data level 0

Diagram alir data level 0 atau sering disebut diagram konteks adalah sebuah gambar yang menunjukkan ruang lingkup dari sebuah sistem yaitu interaksi antar entitas. Dalam sistem identifikasi penyakit eksantema virus menggunakan case-base reasoning menunjukkan adanya hubungan antar entitas pakar dan user. Dalam diagram konteks pada gambar pakar memberikan masukan kedalam sistem berupa data penyakit eksantema virus, data gejala dan data gejala per kasus dan mendapatkan keluaran berupa data penyakit eksantema virus, data gejala, data gejala per kasus dan data new gejala yang dimasukkan oleh user. Data new gejala akan dimasukkan secara otomatis oleh sistem jika masukan user tidak pernah ada pada kasus yang tersimpan dalam database. 


\section{b. Diagram Alir Data Level 1}

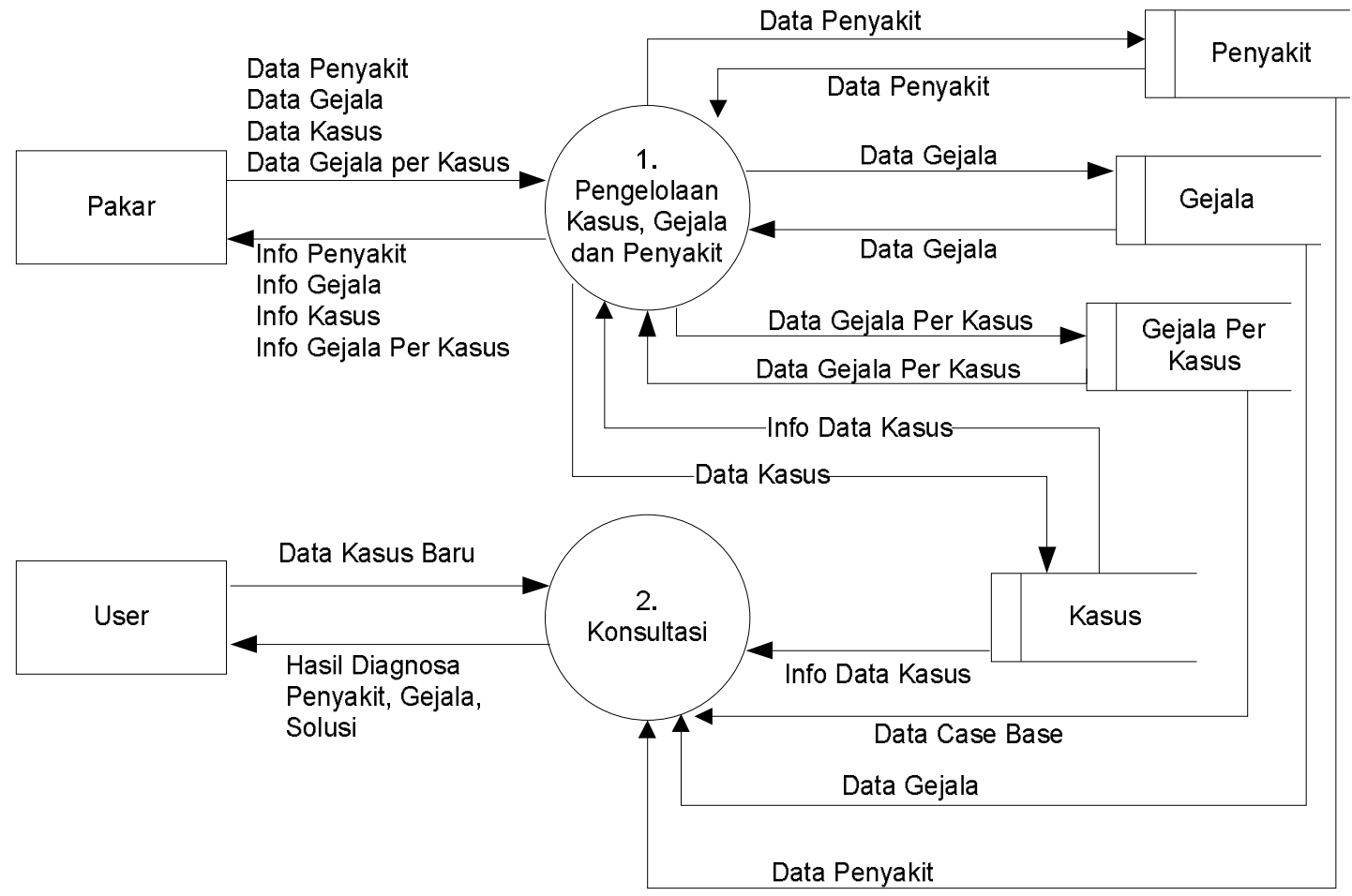

Gambar 3. Diagram alir data level 1

Penjelasan dari gambar pada diagram alir data level 1 adalah adanya dua proses yang terbagai dari level 0 yang menjadi proses 1 dan proses 2 . Proses 1 adalah proses pengelolaan data penyakit, gejala dan kasus yang dilakukan oleh pakar. User akan memasukkan data gejala kasus baru ke dalam proses 2 yaitu proses konsultasi. Sistem akan membandingkan gejala baru dengan data pada tabel gejala, tabel penyakit eksantema virus dan tabel gejala per kasus. User akan mendapatkan keluaran berupa hasil diagnosa atau identifikasi penyakit eksantema virus, nama gejala dan solusi.

\section{Perancangan Tabel dalam Basis Data}

\section{a. Tabel Penyakit}

Tabel penyakit digunakan untuk menyimpan data penyakit-penyakit akibat eksantema virus. Struktur tabel penyakit dapat dilihat berikut ini.

Tabel 2. Penyakit

\begin{tabular}{|l|l|l|l|l|}
\hline No & Nama Field & Tipe Data & Ukuran & Keterangan \\
\hline 1 & Idpenyakit & Varchar & 5 & kode penyakit (primary key) \\
\hline 2 & Nama & Varchar & 40 & Nama penyakit \\
\hline 3 & Solusi & Varchar & 200 & Solusi penyakit \\
\hline
\end{tabular}

\section{b. Tabel Gejala}

Tabel gejala digunakan untuk menyimpan data gejala atau gejala yang terjadi pada penderita suatu penyakit, field-field dari tabel gejala dapat dilihat pada tabel berikut ini. 
Tabel 3. Gejala

\begin{tabular}{|l|l|l|l|l|}
\hline No & Nama Field & Tipe Data & Ukuran & Keterangan \\
\hline 1 & Idgejala & Varchar & 5 & kode gejala (primary key) \\
\hline 2 & Nama & Varchar & 40 & nama gejala \\
\hline 3 & Bobot & Tinyint & 1 & Nilai bobot \\
\hline
\end{tabular}

\section{c. Tabel Casebase (Gejala per Kasus)}

Tabel casebase digunakan untuk menyimpan data gejala per jenis penyakit. Struktur tabel casebase adalah sebagai berikut :

Tabel 4. Casebase

\begin{tabular}{|l|l|l|l|l|}
\hline No & Nama Field & Tipe Data & Ukuran & Keterangan \\
\hline 1 & Idkasus & Varchar & 5 & Id Kasus (foreign key) \\
\hline 2 & Idgejala & Varchar & 5 & Id gejala (foreign key) \\
\hline
\end{tabular}

\section{d. Tabel Kasus}

Tabel Kasus digunakan untuk menyimapan data kasus dan menjadi master bagi tabel Casebase, penyimpanan tabel dilakukan melalui form casebase.

Tabel 5. Kasus

\begin{tabular}{|l|l|l|l|l|}
\hline No & Nama Field & Tipe Data & Ukuran & Keterangan \\
\hline 1 & Idkasus & Varchar & 5 & Id kasus (primary key) \\
\hline 2 & NamaPasien & Varchar & 40 & Nama pasien \\
\hline 3 & Tanggal & Date & 8 & Tanggal retain \\
\hline 4 & JenisKelamin & Varchar & 1 & Jenis kelamin pasien \\
\hline 5 & Umur & Integer & 3 & Umur pasien \\
\hline 6 & IDPenyakit & Varchar & 5 & ID Penyakit (foreign key) \\
\hline
\end{tabular}

\section{e. Tabel Kelompok Umur}

Tabel kelompok umur dipakai untuk mengelompokkan pasien ke dalam golongan usia pasien. Golongan usia ditentukan oleh pakar. Berikut struktur tabel Kelompok Umur.

Tabel 3.6 Kelompok Umur

\begin{tabular}{|l|l|l|l|l|}
\hline No & Nama Field & Tipe Data & Ukuran & Keterangan \\
\hline 1 & KelompokUmur & Varchar & 1 & Id kelompok (varchar) \\
\hline 2 & Awal & Integer & 3 & Nilai awal \\
\hline 3 & Akhir & Integer & 3 & Nilai Akhir \\
\hline 4 & Keterangan & Varchar & 200 & Keterangan kelompok umur \\
\hline
\end{tabular}

\section{f. Tabel Admin}

Tabel admin dipakai untuk keperluan login ke dalam sistem dan sebagai validasi pengguna sistem. Penggna adalah bersatus admin. Berikut struktur tabel Admin.

Tabel 3.7 Admin

\begin{tabular}{|l|l|l|l|l|}
\hline No & Nama Field & Tipe Data & Ukuran & Keterangan \\
\hline 1 & Username & Varchar & 8 & Id Login (Primary Key) \\
\hline 2 & Password & Integer & 8 & Password login \\
\hline 3 & Jabatan & Integer & 1 & Jabatan apakah sebagai admin atau user \\
\hline 4 & NamaLengkap & Varchar & 40 & Nama admin \\
\hline 5 & ID & Integer & 3 & ID Admin \\
\hline
\end{tabular}




\section{Perancangan Relasi Antar Tabel}

Hubungan atau relasi antar tabel ada pada gambar berikut ini.

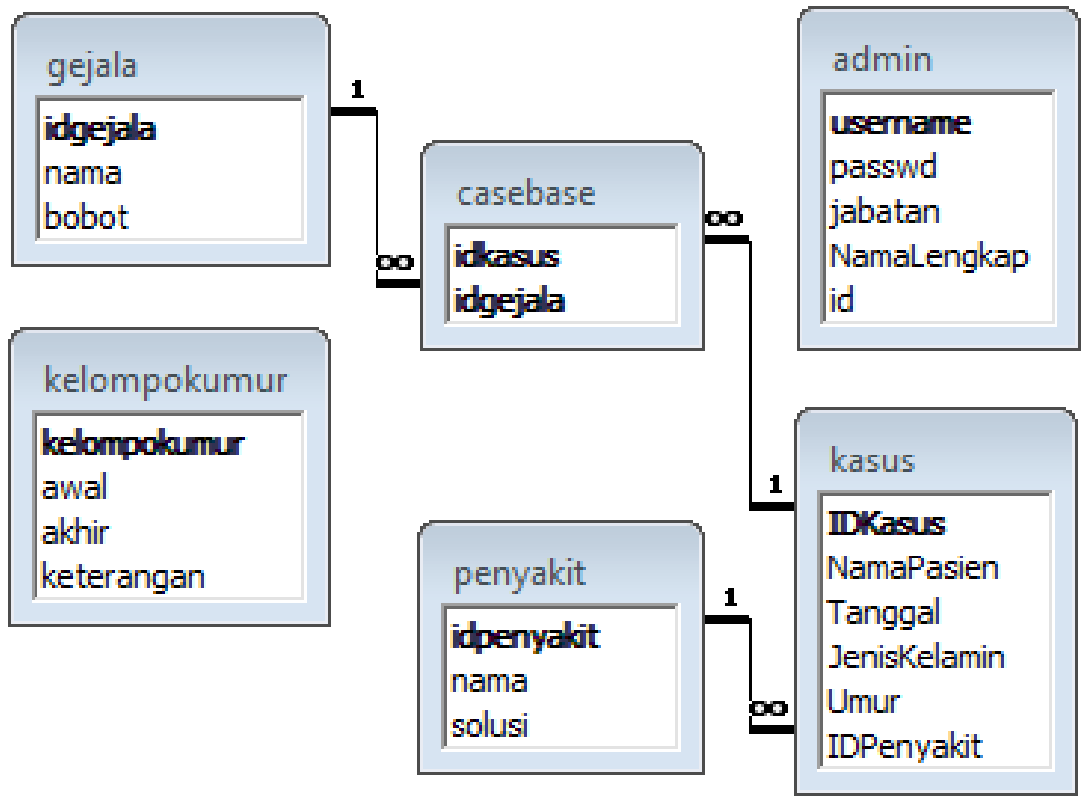

Gambar 4. Relasi antar tabel

Tabel penyakit eksantema virus memliliki relasi dengan tabel casebase dengan relasi dari satu ke banyak. Tabel gejala memiliki relasi dengan tabel casebase dan tabel newcase, dengan relasi satu ke banyak dari tabel gejala ke tabel casebase dan tabel newcase.

\section{Perancangan Proses Indexing}

Jika diketahui jenis-jenis penyakit akibat eksantema virus adalah sebagai berikut :

\begin{tabular}{|l|}
\hline Penyakit akibat Eksantema virus \\
\hline 1 = Variola \\
\hline 2 = Cacar Air \\
\hline 3 = Campak \\
\hline
\end{tabular}

Kemudian juga didata jenis-jenis gejala penyakit akibat eksantema virus dimana sebagian gejalanya adalah sebagai berikut :

\begin{tabular}{|c|l|}
\hline IDGejala & \\
\hline G1 & Demam tinggi \\
\hline G2 & Sakit kepala \\
\hline G3 & Menggigil \\
\hline G4 & Muntah \\
\hline G5 & Timbul ruam (kemerahan kulit) \\
\hline G6 & Ruam (kemerahan kulit) berupa macula mendatar \\
\hline G7 & Ruam (kemerahan kulit) gatal \\
\hline G8 & $\begin{array}{l}\text { Ruam (kemerahan kulit) cepat berubah menjadi papula (menonjol) kemudian vesikel } \\
\text { (lepuhan berisi cairan) }\end{array}$ \\
\hline G9 & Demam ringan \\
\hline G10 & Mengalami gangguan pernafasan \\
\hline
\end{tabular}


Kemudian Range usia ditentukan sebagai berikut :

\begin{tabular}{|l|}
\hline Range Usia \\
\hline $1=$ Usia $0-12$ Tahun (Anak-anak) \\
\hline $2=$ Usia 13 - 22 Tahun (Remaja) \\
\hline $3=$ Usia 23 - 40 Tahun (Dewasa) \\
\hline 4 = Usia 41 - 55 Tahun (Setengah Baya) \\
\hline $5=$ Usia 55 - 100 Tahun (Manula) \\
\hline
\end{tabular}

Jika kasus pendataan penyakit akibat eksantema virus diatas disimpan dalam database dan diindex dalam aturan tertentu maka susunan setiap kasus adalah sebagai berikut :

\begin{tabular}{|r|r|r|r|r|r|r|r|r|r|r|r|r|r|}
\hline Nomor & Sex & Usia & G1 & G2 & G3 & G4 & G5 & G6 & G7 & G8 & G9 & G10 & Penyakit \\
\hline 1 & 1 & 4 & 1 & 1 & 1 & 0 & 0 & 0 & 0 & 1 & 0 & 0 & 1 \\
\hline 2 & 1 & 3 & 1 & 1 & 1 & 0 & 0 & 0 & 0 & 1 & 0 & 0 & 2 \\
\hline 3 & 2 & 5 & 1 & 1 & 1 & 1 & 0 & 0 & 1 & 0 & 1 & 1 & 3 \\
\hline 4 & 1 & 5 & 1 & 1 & 1 & 0 & 0 & 0 & 0 & 0 & 0 & 0 & 2 \\
\hline 5 & 1 & 4 & 1 & 1 & 1 & 1 & 0 & 0 & 0 & 0 & 0 & 1 & 3 \\
\hline 6 & 2 & 5 & 1 & 1 & 1 & 0 & 0 & 1 & 0 & 1 & 0 & 0 & 2 \\
\hline 7 & 1 & 4 & 1 & 1 & 1 & 0 & 1 & 0 & 0 & 0 & 1 & 1 & 3 \\
\hline 8 & 1 & 5 & 1 & 1 & 1 & 0 & 0 & 0 & 0 & 1 & 0 & 0 & 1 \\
\hline 9 & 1 & 4 & 1 & 1 & 1 & 0 & 0 & 0 & 1 & 0 & 0 & 1 & 2 \\
\hline 10 & 2 & 4 & 1 & 1 & 1 & 1 & 0 & 1 & 0 & 1 & 1 & 1 & 3 \\
\hline 11 & 1 & 5 & 1 & 1 & 1 & 0 & 0 & 0 & 0 & 0 & 0 & 0 & 2 \\
\hline 12 & 1 & 4 & 1 & 1 & 1 & 1 & 0 & 0 & 0 & 0 & 0 & 1 & 3 \\
\hline
\end{tabular}

Keterangan

Sex

G1 sd G10

: Jenis kelamin, $1=$ Laki-laki, $2=$ Perempuan

: Gejala $1 \mathrm{~s} / \mathrm{d} 10$, dengan 1 = ada gejala tersebut, $0=$ tidak terjadi gejala tersebut

\section{Perancangan Proses Retrieve dan Similarity}

Proses retrieve data kasus yang mirip dilakukan pada saat proses konsultasi. Pengguna memasukkan usia dan jenis kelamin pasien, serta memilih gejala-gejala yang sesuai kondisi pasien. Kemudian aplikasi akan mencari data kasus yang mirip dengan penyakit pasien baru dilihat dari gejalanya. Jika diperoleh 3 kasus yang mirip maka dilakukan pencarian similaritas dengan menggunakan teknik Probabilitas Bayes.

Contoh : dari proses pencarian similaritas diperoleh ada 3 kasus yang mirip yaitu kasus $\mathrm{K} 1$, K2, dan K3. Ketiga kasus tersebut ada yang gejalanya sama dengan pasien baru dan ada yang tidak sama. Jika gejala sama diberi tanda S (sama gejalanya) dan jika tidak sama atau tidak terpenuhi diberi tanda B (beda/belum terpenuhi) :

\begin{tabular}{|l|l|l|l|l|}
\hline ID. & Gejala & $\begin{array}{l}\text { Kasus } \\
\text { K1 }\end{array}$ & $\begin{array}{l}\text { Kasus } \\
\text { K2 }\end{array}$ & $\begin{array}{l}\text { Kasus } \\
\text { K2 }\end{array}$ \\
\hline G1. & Demam tingi & S & S & S \\
\hline G2. & Sakit kepala & S & S & S \\
\hline G3. & Menggigil & B & & \\
\hline G4. & Muntah & & & \\
\hline G5. & Timbul ruam (kemerahan kulit) & & $\mathrm{B}$ & \\
\hline G6. & Ruam (kemerahan kulit) berupa macula mendatar & & & B \\
\hline G7. & Ruam (kemerahan kulit) gatal & & & \\
\hline G8. & $\begin{array}{l}\text { Ruam (kemerahan kulit) cepat berubah menjadi papula } \\
\text { (menonjol) kemudian vesikel (lepuhan berisi cairan) }\end{array}$ & & B & B \\
\hline G9. & Demam ringan & & & \\
\hline G10. & Mengalami gangguan pernafasan & & B & B \\
\hline Jumlah FAKTA & $\mathbf{3}$ & $\mathbf{5}$ & $\mathbf{5}$ \\
\hline Fakta terpenuhi & $\mathbf{2}$ & $\mathbf{2}$ & $\mathbf{2}$ \\
\hline Fakta tidak terpenuhi & $\mathbf{1}$ & $\mathbf{3}$ & $\mathbf{3}$ \\
\hline
\end{tabular}


Berdasarkan tabel diatas perlu dihitung teorema Probabilitas Bayes.

Ada 3 Penyakit, maka probabilitas tiap penyakit diantara 3 adalah :

$$
\begin{aligned}
& P(K 1)=0.33 \\
& P(K 2)=0.33 \\
& P(K 35)=0.33
\end{aligned}
$$

Probabilitas $S$ (sama gejalanya) di setiap penyakit adalah :

$\mathrm{P}(\mathrm{S} \mid \mathrm{K} 1)=0.66 \quad(\mathrm{~S}$ di penyakit K1)

$P(S \mid K 2)=0.4(S$ di penyakit K2)

$\mathrm{P}(\mathrm{S} \mid \mathrm{K} 5)=0.4$ (S di penyakit K3)

Probabilitas $\mathrm{S}$ (sama gejalanya) di semua penyakit :

$$
\begin{aligned}
P(S) & =0.33^{\star} 0.66+0.33^{\star} 0.4+0.33^{\star} 0.4 \\
& =0.2178+0.132+0.132 \\
& =0.4818
\end{aligned}
$$

Probabilitas $\mathrm{S}($ sama gejalanya) di $\mathrm{K} 1$ terhadap semua probabilitas di semua penyakit :

$$
\begin{aligned}
\mathrm{P}(\mathrm{K} 1 \mid \mathrm{S}) & =\mathrm{P}(\mathrm{S} \mid \mathrm{K} 1)^{\star} \mathrm{P}(\mathrm{K} 1) / \mathrm{P}(\mathrm{S}) \\
& =0.66^{\star} 0.33 / 0.4818 \\
& =0.452
\end{aligned}
$$

Probabilitas $\mathrm{S}$ (sama gejalanya) di K2 terhadap semua probabilitas di semua penyakit :

$$
\begin{aligned}
\mathrm{P}(\mathrm{K} 2 \mid \mathrm{S}) & =\mathrm{P}(\mathrm{S} \mid \mathrm{K} 2)^{\star} \mathrm{P}(\mathrm{K} 2) / \mathrm{P}(\mathrm{S}) \\
& =0.4^{*} 0.33 / 0.4818 \\
& =0.274
\end{aligned}
$$

Probabilitas $\mathrm{S}$ (sama gejalanya) di K3 terhadap semua probabilitas di semua penyakit :

$$
\begin{aligned}
\mathrm{P}(\mathrm{K} 3 \mid \mathrm{S}) & =\mathrm{P}(\mathrm{S} \mid \mathrm{K} 3)^{\star} \mathrm{P}(\mathrm{K} 3) / \mathrm{P}(\mathrm{S}) \\
& =0.4^{*} 0.33 / 0.4818 \\
& =0.274
\end{aligned}
$$

Jadi kasus terdekat adalah kasus K1 dengan tingkat kemiripan sebesar 0.452 , atau $45,2 \%$ dengan kasus baru.

\section{IMPLEMENTASI SISTEM}

\subsection{Kebutuhan Software}

Software yang dibutuhkan dalam proses pengembangan adalah software berbasis windows sebagai berikut :

Tabel 3.1 Software requirements

\begin{tabular}{|l|l|l|}
\hline No. & Nama Software & Fungsi \\
\hline 1. & $\begin{array}{l}\text { Microsoft Access } \\
\text { database }\end{array}$ & Sebagai Database. \\
\hline 2. & ADO Data Control & $\begin{array}{l}\text { Sebagai komponen untuk koneksi antara database dan } \\
\text { Delphi 7. }\end{array}$ \\
\hline 3. & Delphi 7 & Sarana development tool \\
\hline
\end{tabular}

\subsection{Interface Aplikasi}

Form ini berfungsi untuk mendata kasus-kasus penyakit akibat eksantema virus. Kasuskasus diperoleh dari kasus-kasus yang lalu atau kasus baru hasil proses reasoning. Maka form ini terletak pada tahap RETAIN dalam siklus case based reasoning. Setiap kasus yang hendak disimpan perlu ditentukan gejala dan penyakit yang dideritanya. 


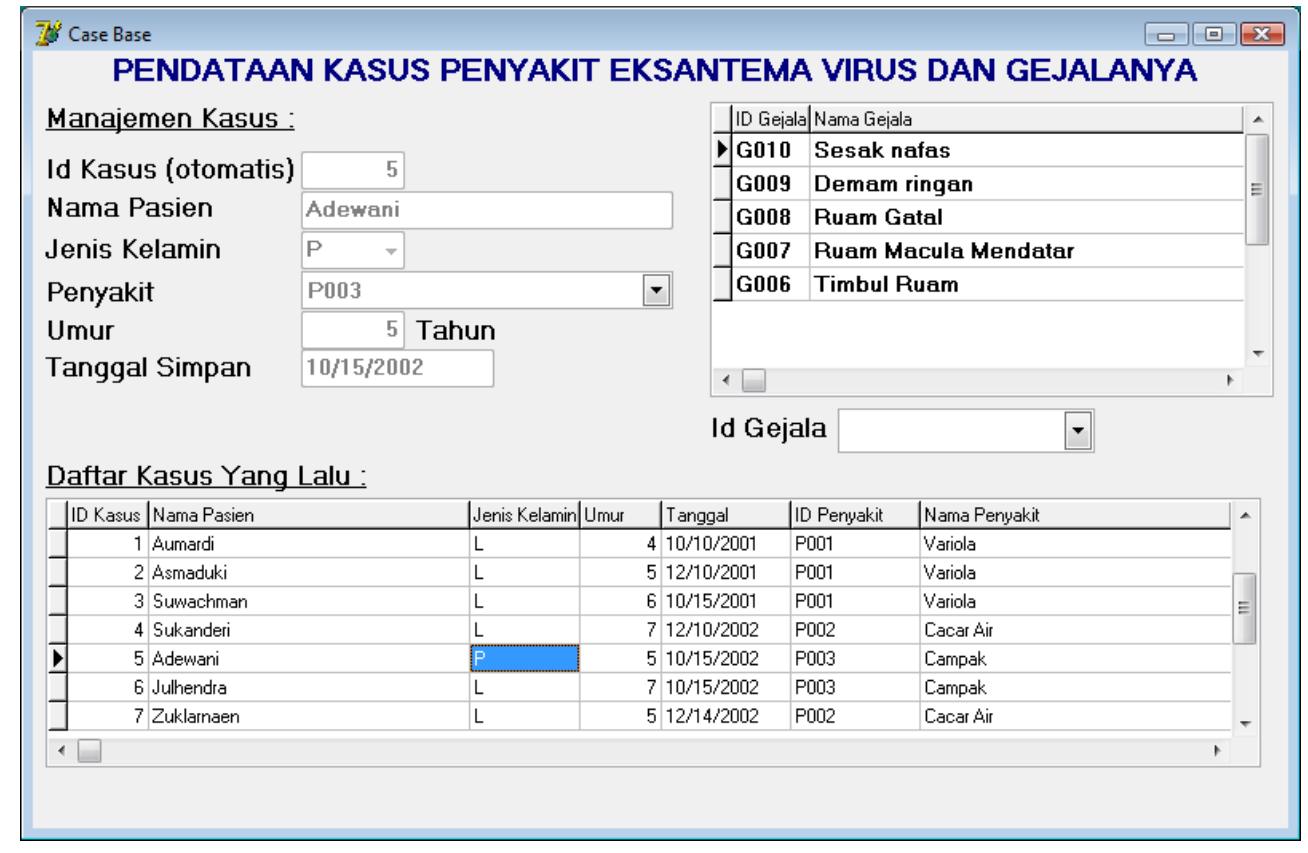

Gambar 5. Form Pencatatan Kasus Penyakit Eksantema

\subsection{Form Identifikasi Kasus}

Form identifikasi berguna untuk menentukan/mengidentifikasi penyakit akibat eksantema virus. Di sini proses retrieve kasus lama dilakukan. Pengguna memasukkan usia, jenis kelamin pasien, dan gejala-gejalanya. Kemudian klik tombol proses diagnosa, hasilnya adalah daftar kasus penyakit yang tercatat di masa lalu dan mirip gejalanya pada penderita tersebut. Pada form tersebut juga ditampilkan hasil diagnosa yang sesuai dengan kasus baru.

Form di bawah ini merupakan contoh hasil diagnosa pada pasien dengan gejala demam tinggi, sakit kepala, menggigil dan timbul ruam. Berdasarkan kasus-kasus yang pernah ada, gejala ini menandakan pasien tersebut menderita penyakit Variola. Jika gejala ditambahkan, misalnya ada tambahan gejala baru yaitu muntah, maka sistem akan menemukan beberapa kasus mirip dengan gejala tersebut. Jika terjadi beberapa kasus mirip maka perlu dihitung menggunakan metode Probabilitas Bayes seberapa dekat kasus baru ini dengan kasus-kasus mirip yang pernah ada.

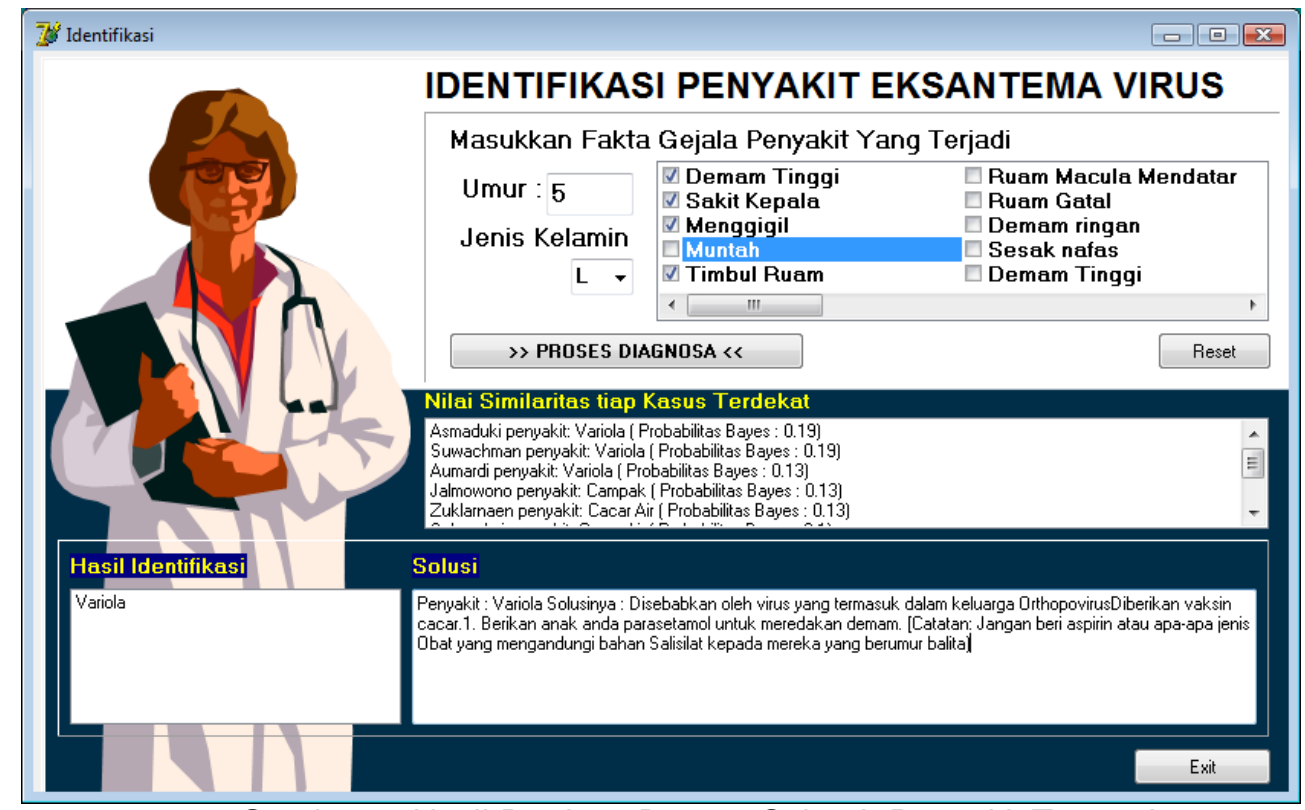

Gambar 6. Hasil Retrieve Berupa Sebuah Penyakit Tunggal 


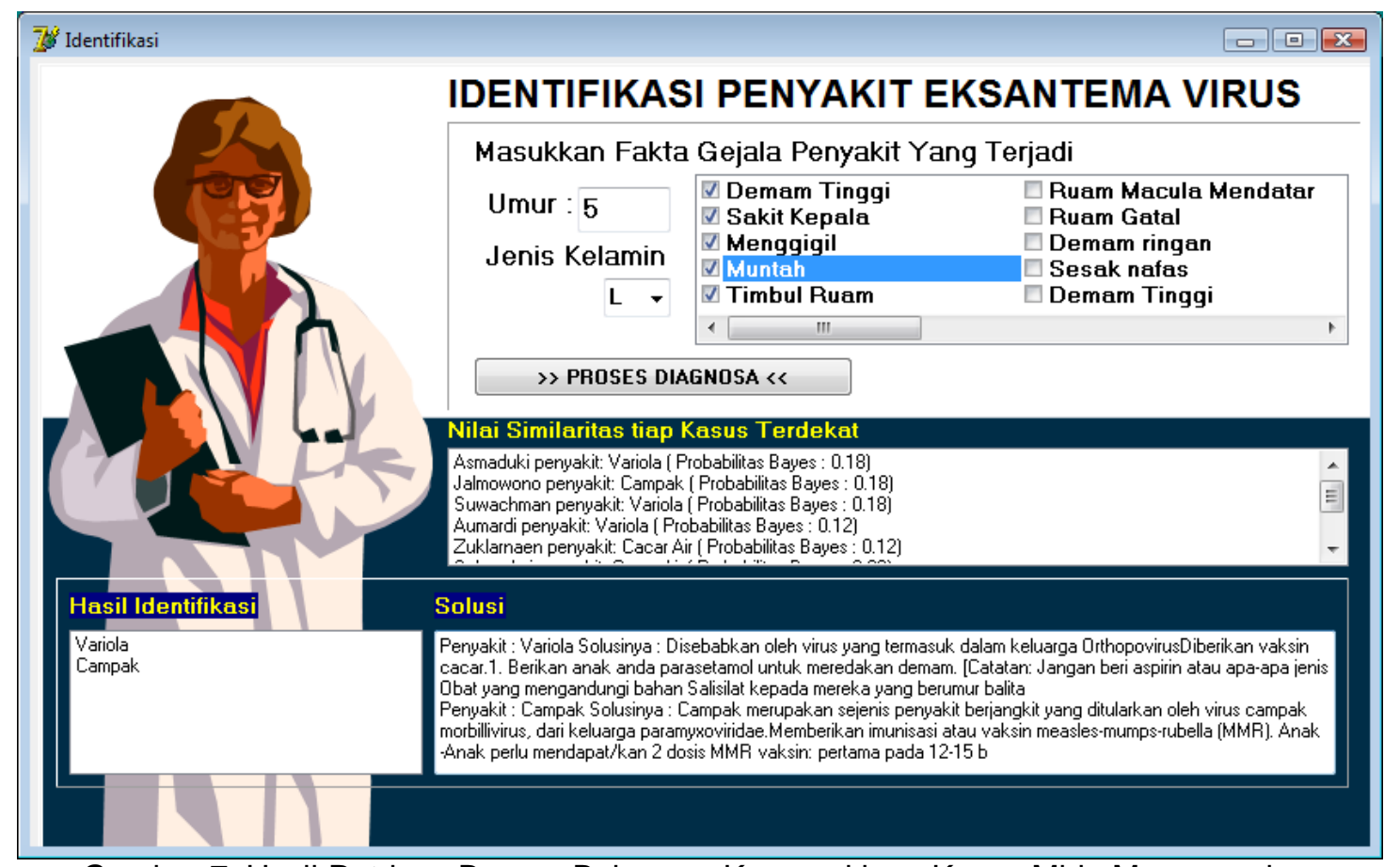

Gambar 7. Hasil Retrieve Berupa Beberapa Kemungkinan Kasus Mirip Menggunakan Probabilitas Bayes

\section{KESIMPULAN DAN SARAN}

\subsection{Kesimpulan}

1. Case based reasoning dapat digunakan untuk membangun sistem pakar untuk identifikasi penyakit akibat eksantema virus. Proses dimulai dengan cara memasukkan kasus yang lama ke dalam database kasus, kemudian dilakukan proses pengindexan kasus untuk mempercepat proses pencarian kasus. Jika ada kasus baru maka solusinya dicari dari data kasus lama dengan kimiripan tertinggi untuk diambil solusinya.

2. Metode Probabilitas Bayes dapat digunakan untuk mempertimbangkan kasus yang paling mirip dari database kasus terindex saat proses retrieve kasus. Sehingga apapun gejala penyakit baru yang hendak di diagnosa, sistem tetap dapat memberikan penyelesaian kasus.

\subsection{Saran}

1. Untuk pengembangan sistem selanjutnya indexing dapat dilakukan dengan menggunakan algoritma lain misalnya C45, K-Nearest Neighbor dan sebagainya.

2. Untuk jumlah kasus yang besar similarity dapat dilakukan dengan mengelompokkan (classification) terlebih dahulu. Proses pencarian cukup dilakukan pada kelompok terdekat saja. 


\section{DAFTAR PUSTAKA}

Giarratano, J., Riley, G., 1993, Expert Systems : Principles and Programming, PWS Publishing Company, Boston.

Kusumadewi, S., 2003, Artificial Intelligence, Graha IImu : Yogyakarta.

Pal, Shankar K. And Shiu, Simon C.K., Foundations of Soft Case Based Reasoning. Willey \&

Sons, Inc. Canada. pp $64-67.2004$.

Turban, Efrain, E. Aronson, Jay, 2005, Decision Support Systems and Intelligent Systems, Pearson Education, inc, New Jersey.

Watson,I." Applying Case-Based Reasoning.Techniques For Enterprise Systems".

Widjaja, B. H., Tina, W.W., 2000, Eksantema Virus Pada Anak, Diagnosis dan Penatalaksanaannya, Media Dermato - Venereologica Indonesiana: Dermatologi Anak, Vol. 24 No. 4. 